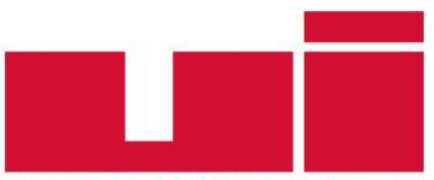

ULLUSLARARASIILIȘKiLER

Akademik Dergi

Yayın ilkeleri, izinler ve abonelik hakkında ayrıntılı bilgi:

E-mail: bilgi@uidergisi.com.tr

Web: www.uidergisi.com.tr

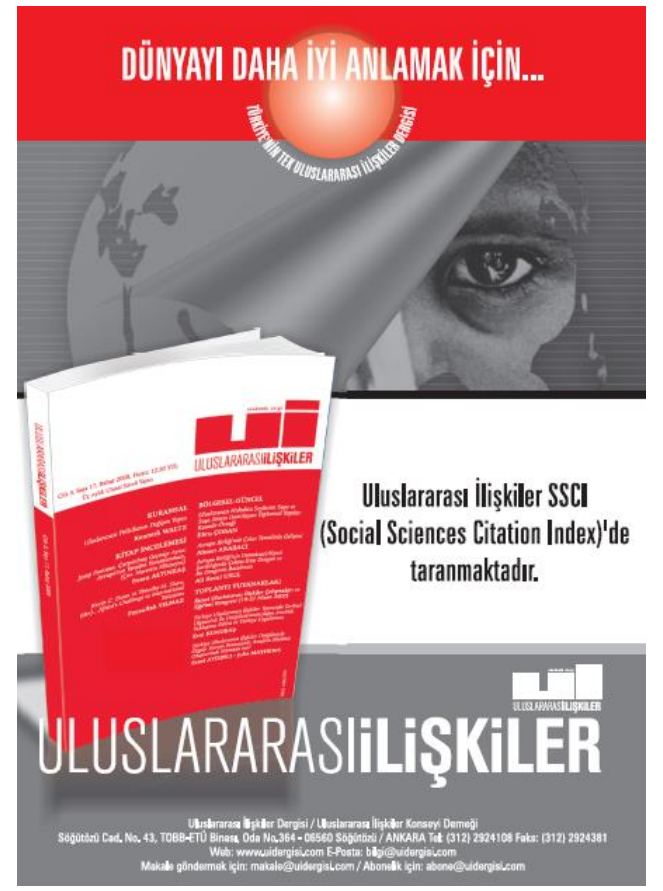

\title{
Paris Anlaşmasını İklim Adaleti Perspektifinden Değerlendirmek
}

\section{Yasemin KAYA*}

* Yrd. Doç. Dr., Siyaset Bilimi ve Kamu Yönetimi Bölümü, Uludağ Üniversitesi

Bu makaleye atıf icin: Kaya, Yasemin, “ Paris Anlaşmasını İklim Adaleti Perspektifinden Değerlendirmek", Uluslararası Illişkiler, Cilt 14, Sayı 54, 2017, s. 87-106.

Bu makalenin tüm hakları Uluslararası İlişkiler Konseyi Derneği'ne aittir. Önceden yazılı izin alınmadan hiç bir iletişim, kopyalama ya da yayın sistemi kullanılarak yeniden yayımlanamaz, çoğaltılamaz, dağıtılamaz, satılamaz veya herhangi bir şekilde kamunun ücretli/ücretsiz kullanımına sunulamaz. Akademik ve haber amaçlı kısa alıntılar bu kuralın dışındadır.

Aksi belirtilmediği sürece Uluslararası Illişkiler'de yayınlanan yazılarda belirtilen fikirler yalnızca yazarına/yazarlarına aittir. UİK Derneğini, editörleri ve diğer yazarları bağlamaz. 


\title{
Paris Anlaşmasını İklim Adaleti Perspektifinden Değerlendirmek
}

\author{
Yasemin KAYA \\ Yrd. Doç. Dr., Siyaset Bilimi ve Kamu Yönetimi Bölümü, İIBF, Uludağ Üniversitesi, Bursa. \\ E-posta: yaseminkahveci@uludag.edu.tr
}

\section{ÖZET}

İklim değişikliği sorunun moral boyutuna işaret eden bir kavram olarak iklim adaleti, özellikle son yirmi yıldır iklim tartışmalarının odağında olan bir konudur. İklim değişikliği sorunun kurılgan topluluklar üzerindeki orantısız etkisini merkeze alan iklim adaleti, aynı zamanda iklim müzakerelerinin de en tartışmalı konularından birini oluşturmaktır. Öyle ki, Kyoto sonrası dönem için oluşturulacak anlaşmanın iklim adaletinin sesine kulak vermesi ve yeni rejimin adalet ve eşitlik ilkeleri üzerine temellenmesi gerektiği fikri sıklıkla dile getirilen bir talep olmuştur. Çalışma bu çerçevede, iklim adaleti söylemi içinde yer bulan farklı talepleri belirlemeyi ve bu taleplerin Paris Anlaşması́nda ne ölçüde karşılandığını değerlendirmeyi amaçlamaktadır.

Anahtar Kelimeler: İklim Değişikliği, İklim Adaleti, Paris Anlaşması, İklim Adaleti Hareketi, Kırılganlık.

\section{Evaluation of Paris Agreement from the Perspective of Climate Justice}

\begin{abstract}
Climate justice as a concept indicating the moral dimension of the problem of climate change has been a subject in the center of climate debates especially in the past two decades. Climate justice that centers on the disproportionate impacts of climate change particularly on vulnerable communities also constitutes one of the most contentious subjects of the climate negotiations. Actually, the fact that the treaty to be created for the post-Kyoto period should lend an ear to voice of climate justice and the idea that the new regime should be based on justice and equality has turned out to be a frequently expressed demand. Within this framework, the study aims to determine the different demands within the discourse of climate justice and evaluate to what extent these demands are met in the Paris Agreement.
\end{abstract}

Keywords: Climate Change, Climate Justice, Paris Agreement, Climate Justice Movement, Vulnerability. 


\section{Giriş}

İklim adaleti, iklim değişikliğinin yaşanmasında en az sorumluluğa sahip olanların, iklim değişikliğinin sonuçlarından ilk ve en fazla etkilenenler/etkilenecekler olması şeklinde tezahür eden temel bir adaletsizliği dile getirmek için kullanılmaktır. Söz konusu orantısız etkiler ve bunların giderilmesi, iklim değişikliğine ilişkin tartışmaların merkezinde yer almakta ve uluslararası iklim müzakerelerinin gündemini önemli ölçüde meşgul etmektedir. Gerçekten de Birleşmiş Milletler İklim Değişikliği Çerçeve Sözleşmesi'nin (BMİDÇS) kabul edildiği 1992 yılından bugüne iklim müzakerelerini çıkmaza sürükleyen de, rejimin sürekliliğini belirleyen de bu temel sorun bağlamında ortaya çıkan çatışma ya da uzlaşılar olmuştur. ${ }^{1}$ Kuzey ve Güney ülkeleri ya da gelişmiş ve gelişmekte olan ülkeler arasındaki eşitlik, hak ve sorumluluk gibi konulardaki tartışmalar büyük ölçüde iklim adaletinin farklı boyut ve yorumları üzerine temellenmiştir.

İklim değişikliğinin olumsuz sonuçlarından bazı ulusların daha fazla etkilendiği ya da etkileneceği, bilimsel olarak ortaya konan ve genel kabul gören bir gerçektir. Hükümetler arası İklim Değişikliği Panelinin (Intergovermental Panel on Climate Change-IPCC) Beşinci Değerlendirme Raporuna ilişkin 2014 Sentez Raporu, iklim değişikliğinin yarattığı risklerin eşitsiz bir biçimde dağıldığını ve dezavantajlı halklar üzerinde daha büyük bir etki yarattığını ortaya koymaktadır. ${ }^{2}$ İklim adaleti aslında iklim değişikliğiyle ilgili fayda (salınıma bağlı ekonomik büyüme ve yaşam standardı) ve maliyetlerin (çevresel bozulma, kuraklık, tatlı su kaynaklarının azalması, sağlık vb.) eşitsiz dağıldığını ortaya koyan bilimsel bir iddia üzerine temellenir. Ancak adaletin ya da adaletsizliğin normatif doğası, iklim adaleti tartışmalarını çok daha geniş bir bağlama taşır. Bu noktada iklim adaleti söylemi sadece fayda ve maliyetlerin eşitsiz dağılımı sorununu dile getirmez, aynı zamanda bu adaletsizlikle bağlantılı olarak karar alma süreçlerine katılımı, kaynaklara eşit erişim hakkını, ekonomik ve toplumsal alanlarda süregelen sistemsel eşitsizlikleri, nesil içi ve nesiller arası adaleti de dile getirir. ${ }^{3}$

İklim adaleti söyleminin farklı türden eşitsizlik ve adaletsizliklere temas eden ve bu bağlamda farklı adalet taleplerini içeren esnek ve kapsamlı yapısı, akademik alanda da iklim adaletinin, dağıtıcı adalet, prosedürel adalet, telafi edici/düzeltici adalet ve cezalandırıcı adalet gibi farklı adalet teorileri ışığında tartışılmasını beraberinde getirmiştir. ${ }^{4}$ Benzer bir farklılaşma iklim adaleti hareketinde de gözlenmektedir. Geniş bir tabana sahip olan iklim adaleti hareketi, en az üç farklı bölgesel kökenden beslenmekte ve oldukça geniş bir yelpazede yer alan talepleri iklim adaleti potasında eritmektedir. ${ }^{5}$ İklim adaleti tartışmalarının yoğunlaştığı bir diğer platform olan iklim müzakereleri bağlamında da özellikle ülkelerin çıkarlarına bağ lı olarak şekillenen, farklı hatta çatışan adalet söylemleri ve talepleriyle karşılaşılabilmektedir.

1 René Audet, “Climate Justice and Bargaining Coalitions: A Discourse Analysis”, International Environmental Agreements: Politics, Law and Economics, Cilt 13, No.3, 2013, s.370.

2 "Climate Change 2014: Synthesis Report", Geneva, Switzerland, Intergovernmental Panel on Climate Change (IPCC), 2015, s.13-16.

3 Gerhard Reese, "Common Human Identity and the Path to Global Climate Justice", Climatic Change, Cilt 134, No.4, 2016,s.524; Shangrila Joshi, "Environmental Justice Discourses in Indian Climate Politics", GeoJournal, Cilt 79, No.6, 2014, s.678; Tim Forsyth, “Climate Justice Is Not Just Ice”, Geoforum, Cilt 54, 2014, s.230.

4 Jewku Ikeme, "Equity, Environmental Justice and Sustainability: Incomplete Approaches in Climate Change Politics", Global Environmental Change, Cilt 13, No.3, 2003, s.197-198; Chukwumerije Okereke, "Climate Justice and the International Regime”, Wiley Interdisciplinary Reviews: Climate Change, Cilt 1, No.3, 2010, s.464.

5 Yerliler ve özellikle Küresel Güney'de yaşayan halkların kırılganlıkla bütünleşen talepleri, Kuzey Amerika'da sivil haklar hareketiyle bütünleşen ırksal eşitsizliklere dayalı çevresel adalet talepleri, Avrupa ve ötesinde küresel adalet hareketi ile bütünleşen ve iklim krizini sistemin krizi olarak gören, onun küresel kapitalizmle bağlantısını sorgulayan anti-kapitalist talepler. Bkz. Brain Tokar, "Democracy, Localism, and the Future of The Climate Movement", World Futures, Cilt 71, No.3-4, 2015, s.69. 
Bu çalışma, iklim adaletine ilişkin akademik yazın, iklim adaleti hareketi ve iklim müzakereleri olmak üzere, iklim adaleti tartışmalarının yoğunlaştığı üç alanın genel bir değerlendirmesini yaparak; iklim adaleti söylemi içinde yer bulan adalet taleplerini belirlemeyi ve bu taleplerin Paris Anlaşması'nda ne ölçüde karşılandığını değerlendirmeyi amaçlamaktadır. Çalışmanın temel iddiası ise iklim adaleti hareketinin gücü ile iklim değişikliğine ilişkin hukuki çıtılar arasında retorik düzeyde güçlü, ancak eylem düzeyinde zayıf bir ilişkinin bulunduğudur. Çalışmada belirlenen amaç doğrultusunda, öncellikle alan yazınından hareketle iklim adaletine ilişkin kavramsal ve kuramsal çerçeve ortaya konmaya çalışılacaktır. Daha sonra iklim adaleti hareketinin taleplerini yansıtan temel dokümanlar değerlendirilecek ve ardından devletlerin müzakere pozisyonları bağlamında, iklim müzakerelerinde ön plana çıkan adalet tartışmaları ele alınacaktır. Bu tartışmayı takiben iklim adaleti söylemi içinde yer bulan talepler belirlenmeye çalışılacak ve son olarak Paris Anlaşması bağlamında bu taleplerin ne ölçüde karşılandığı değerlendirilecektir.

\section{İklim Adaleti: Kavramsal ve Kuramsal Çerçeve}

İklim sisteminde ortaya çıkabilecek ani, geri döndürülemez ve felakete varacak değişimlerin önlenmesi için ısı artışının endüstri öncesi döneme göre (1850-1900) $2^{\circ} \mathrm{C}$ ile sınırlandırılması gerektiği kabul edilmektedir. IPCC raporuna göre $1 s ı$ artışını $2^{\circ} \mathrm{C}$ ile sınırlamak için karbon emisyonlarında 2010 yılı değeri temel alınmak üzere 2050 yılı itibarıyla \%41-78 ve 2100 yılı itibarıla \%78-118 oranında bir azalma gerekmektedir. ${ }^{6}$ Karbon emisyonlarında ciddi bir azaltıma gidilmediği takdirde hali hazırda iklim değişikliğine bağlı olarak gözlemlenen pek çok etkinin şiddetini arttıracağı beklenmektedir. $\mathrm{Bu}$ etkiler, okyanuslarda ısı artışı ve asidifikasyon, deniz seviyesinin yükselmesine bağlı olarak kıyı erozyonu ve tatlı su kaynaklarında kirlenme, ekosistemlerde bozulma ve biyolojik çeşitlilik kaybıdır. Ayrıca başta balıkçılık ve tarım gibi faaliyetlerde olmak üzere ekonomik gerileme, kuraklık ve kuraklığa bağlı olarak su ve gıda güvenliği riski, aşırı hava olaylarına bağlı toplumsal ve ekonomik kayıplar ile can ve mal kaybı da iklim değişikliğine bağlı olarak ortaya çıkabilecek olumsuz etkilerdir. İklim değişikliğinin olumsuz etkileri neticesinde yaşanacak olan göçler ve kültürel soykırım da bu anlamda dikkat çekilmesi gereken bir diğer önemli sorundur. ${ }^{7}$

IPCC, Dünya Kaynakları Enstitüsü (World Resources Institute-WRI) ve İklim Risk İndeksi gibi farklı kaynaklardan sağlanan veriler bu etkilerin özellikle gelişmekte olan ülkeler, en az gelişmiş ülkeler ve küçük ada devletleri gibi kırılganlığı yüksek, buna karşın söz konusu etkilerle başa çıabilme konusunda yeterli kapasiteye sahip olmayan ülkelerde yoğunlaştığını/yoğunlaşacağını ortaya koymaktadır. WRI, iklim değişikliğinin sebep olduğu kayıp ve zararın maliyetin yaklaşık \%80'inin gelişmekte olan ülkeler tarafından yüklenileceğini öngörmektedir. ${ }^{8}$ Yine WRI'dan sağlanan veriye göre, 164 ülke genelinde yapılan araştırmanın sonuçları, her yıl sel felaketlerinden etkilenen nüfusun yaklaşık \% 80'inin az gelişmiş ya da gelişmekte olan 15 ülkede yaşadığını göstermektedir. ${ }^{9}$ Küresel İklim Risk İndeksi 2014 raporuna göre, 1993-2012 yılları arasında aşırı hava olaylarından en fazla etkilenen

6 “Climate Change 2014", s.22.

7 Ibid. s.64-65; Edward A. Page, Climate Change, Justice and Future Generations, Cheltenham UK, Edward Elgar Publishing, 2006, s.45; "Kültürel soykırım", çevresel yıkım nedeniyle kültürel değerlerin ve geleneklerin kaybedilmesini anlatmak üzere kullanılan bir kavramdır. Bkz. Randall S. Abate, "Public Nuisance Suits For The Climate Justice Movement: The Right Thing and The Right Time”, Washington Law Review, Cilt 85, No.2, 2010, s.208.

8 World Resources Institute (WRI), “Climate Resilience”, http://www.wri.org/our-work/topics/climate-resilience, (Erişim Tarihi 22 Şubat 2015).

9 Tionyi Luo et.al., "World's 15 Countries With the Most People Exposed to River Floods", http://www.wri.org/ blog/2015/03/world\%E2\%80\%99s-15-countries-most-people-exposed-river-floods, (Erişim Tarihi 22 Şubat 2016). 
ilk on ülke -sekizi en az gelişmiş ülkeler arasında yer alan- gelişmekte olan ülkelerden oluşmaktadır. Listede yer alan ilk beş ülke Honduras, Myanmar, Haiti, Nikaragua ve Bangladeş'tir. ${ }^{10}$

Sorunun önemli bir boyutu da söz konusu ülkelerin çözüm amaçlı politikalardan da olumsuz şekilde etkilenmesidir. Karbon denkleştirme odaklı Temiz Kalkınma Mekanizması ve Ormansızlaşmadan ve Orman Alanlarındaki Bozulmadan Kaynaklanan Emisyonların Azaltılması'na (Reducing Emissions From Deforestation and Forest Degradation-REDD) yönelik teşvikler, emisyon hakları ticareti ve kaynak kullanım haklarının özelleştirilmesi gibi piyasa mekanizmaları bu ülkelerde çevresel bozulmayı, ekonomik ve toplumsal eşitsizlikleri daha da artırmaktadır. ${ }^{11}$

İklim değişikliğine bağlı etkilerin önlenmesinde sera gazı emisyonlarının azaltılması temel bir önceliktir. Ancak, emisyonlar sıfırlansa bile atmosferdeki ısı artışının uzun yıllar süreceği, dolayısıyla iklim değişikliğine bağlı etkilerin devam edeceği öngörülmektedir. $\mathrm{Bu}$ nedenle iklim değişikliğinin etkileri karşısında savunmasız olan kırılgan toplulukların kapasitelerinin güçlendirilmesi için adaptasyon politikalarına ihtiyaç bulunmaktadır. Kırılganlık, iki temel faktör bağlamında açıklanmaktadır; riske açık olma ya da maruz kalma ve riske karşı koyacak ya da riskle baş edebilecek kaynaklardan yoksun olma. ${ }^{12}$ Roberts ve Parks, bir ulusun iklimsel felaketler karşısındaki kırılganlığını sosyal, ekonomik ve tarihsel koşullara bağlı yapısal nedenler üzerinden açıklamaktadırlar. Buna göre, kolonyal mirasın etkisinde sınırlı sayıda ve düşük fiyatlı ürünün ihracatına dayalı zayıf bir ekonomik yapı, coğrafi dezavantajlar, güçsüz ve kötü yönetim kırılganlığın başlıca nedenleri olarak görülmektedir. ${ }^{13}$

Azaltım ve adaptasyon politikaları, iklim adaletinin orantısız etkiler üzerindeki vurgusuna temel teşkil eden kırılganlık olgusuyla yakından ilgilidir. Zira azaltım, riske açık olma ya da maruz kalma olasılığını azaltmakta; adaptasyon ise riskten korunmak ya da riskle baş edebilmek için gerekli kaynağı sağlamaktadır. ${ }^{14}$ Bu nedenle iklim müzakerelerinin odağındaki temel tartışma konuları olan azaltım ve adaptasyon, aynı zamanda iklim adaletinin de merkezinde yer almaktır. Ancak azaltım ve adaptasyonla ilgili konuların adaletle olan bağlantısı karmaşıktır ve bu bağlantıyı adaletin tek bir yorumu üzerinden açılamak güçtür. Başta dağıtıcı adalet, telafi edici/düzeltici adalet, cezalandırıcı adalet ve prosedürel adalet olmak üzere adaletin farklı boyutlarının dikkate alınmasını gerektirmektedir.

Adil bir azaltım politikasının nasıl sağlanacağı özünde bir paylaşım/dağıtım sorunudur. Ancak neyin, kimler arasında ve nasıl paylaştırılacağına ilişkin sorunlar meseleyi problematik hale getirmektedir. Bu durumda dağıtıcı adalete ek olarak, telafi edici/düzeltici adalet ve cezalandırıcı adalet boyutları da gündeme gelir. Dağıtım sorunuyla ilgili olarak alan yazınındaki tartışmalar üç seçenek üzerine odaklanmaktadır. Seçeneklerden ilki, emisyon haklarının kişi başına paylaşımına işaret etmektedir. Bu seçenekte $2^{\circ} \mathrm{C}$ hedefine uygun olarak hesaplanan karbon bütçesine göre kişi başına

102012 yılı sıralamasındaki ilk beş ülke Haiti, Filipinler, Pakistan Madagaskar ve Fiji'dir. Verilerin sınırlı olması sebebiyle en küçük ülkeler özellikle küçük ada devletleri analize dâhil edilmemiştir. Bkz. Sönke Kreft ve David Eckstein, Global Climate Risk Index 2014, Berlin, Germanwatch, 2013, s.6; 1980-2002 yılları için iklim felaketleri kırılganlık göstergelerine göre ülke sıralaması (ölen, evsiz kalan ve etkilenenlerin sayısına ve ülke nüfusuna oranına göre) için bkz. J. Timmons Roberts ve Bradley C. Parks, A Climate of Injustice: Global Inequality, North-South Politics, and Climate Policy, Cambridge, MIT Press, 2007, s.77-80.

11 Henry Shue, Climate Justice: Vulnerability and Protection, Oxford, Oxford University Press, 2014, s.220; Alexander Popp et.al., "Mechanisms For Avoiding Deforestation and Forest Degradation", Ottmar Edenhofer et.al. (der), Climate Change, Justice and Sustainability, Dordrecht, Springer, 2012, s.289-290.

12 Darrel Moellendorf, “Climate Change Justice”, Philosophy Compass, Cilt 10, No.3, 2015, s.174.

13 Roberts ve Parks, A Climate of Injustice, s.20, 96.

14 Moellendorf, “Climate Change Justice”, s.182. 
emisyon haklarının belirlenmesi ve nüfusları oranında ülkelere tahsis edilmesi önerilmektedir. Ayrıca kişi başına emisyon haklarının belirlenmesinde tarihsel sorumlulukların da dikkate alınması gerektiği vurgulanmaktadır. İkinci seçenek, azaltım yükümlülügünün kümülatif emisyonlar dikkate alınarak, tarihsel sorumluluklar temelinde belirlenmesini ifade eder. Bu seçenek, azaltım sorumluluğunun soruna sebebiyet veren gelişmiş ülkelerce yüklenilmesini öngörür. Üçüncü seçenek ise azaltım yükümlülüklerinin ülkelerin mevcut emisyon düzeyleri üzerinden belirlenmesini içerir. ${ }^{15}$

Adaptasyon politikalarıyla ilgili olarak da alan yazınında tartışmalı görüşlerin olduğu görülmektedir. Ülkelerin teknolojive finansal kaynakların transferini, ödemegüçlerine ve kapasitelerine göre mi yapacakları, yoksa bu transferin gelişmiş ülkelerin gelişmekte olan ülkelere ekolojik borcu kapsamında mı değerlendirileceği; bu konuda kirleten öder ilkesinin mi temel alınacağı, yoksa söz konusu transferin bağış ve yardım gibi keyfi bir gerekçeye mi dayandırılacağı gibi sorular adaptasyon maliyetlerinin paylaşımında da farklı seçeneklerin olduğunu göstermektedir. ${ }^{16}$

Hem azaltım hem de adaptasyon politikaları bağlamında adil sonuçlara ulaşılmasının, adil bir süreci takip etmeye bağlı olduğu da alan yazınında sıkça vurgulanmaktadır. Prosedürel adalete işaret eden bu vurgu, özellikle müzakerelerde eşit temsil fırsatının yaratılmasına dikkat çekmektedir. En basit ifadeyle karardan etkilenen tüm tarafların karar alma sürecine katılmasını ifade eden prosedürel adalet, aynı zamanda tarafların ve onların haklarının tanınması sorununu da kapsamaktadır. ${ }^{17}$

Adaletin bahsigeçen boyutları, adaletsizlik neticesinde vuku bulan olumsuz şartları değiştirmek, adaletsizliği gidermek ve telafi etmek üzerine temellenmiştir. Ancak adalet söylemi, doğrudan bir hak talebi üzerine de inşa edilebilir. Bir insan hakkı olarak iklim adaleti, herkesin eşit doğduğu ve eşit haklara sahip olduğu kabullüyle, yaşamı ve geçimi için gerekli olan elverişli ve yeterli koşullara sahip olma hakkını dile getirmektedir. Bu koşullar sağlıklı ve dengeli bir çevre bağlamında yaşam güvenliğini kapsadığı kadar, kalkınma hakkını da içermektedir. Ancak kalkınma hakkı olarak iklim adaleti, emisyon üretmekle eş anlamlı görülürse, bu önemli bir probleme işaret eder. ${ }^{18}$ Bu noktada $\mathrm{H}$. Shue'nun dikkat çektiği yaşam/geçim için emisyon ve lüks emisyon ayırımını hatırlamak gerekir. ${ }^{19}$ Buradaki asıl vurgu, birey ve toplulukların iyi yaşam kapasitelerinin artırılması üzerine olmalıdır. Çevresel güvenlik, geçim güvenliği ve politik katılım bağlamında iyi yaşam koşularının sağlanması, kişi başına eşit emisyon haklarının sağlanmasından önde gelir. ${ }^{20}$

Sonuç olarak, iklim değişikliğine sebep olma konusunda ülkelerin sorumlulukları birbirinden farklıdır. Ayrıca iklim değişikliğinin etkileri karşında ülkelerin kırılganlık düzeyleri de birbirinden farklıdır. Nihayet, azaltım ve adaptasyon maliyetlerini yüklenme konusunda da ülkeler farklı kapasiteye

15 Okereke, "Climate Justice and the International Regime”, s.464; Brigitte Knopf et.al., "A Global Carbon Market and The Allocation of Emission Rights”, Ottmar Edenhofer et.al. (der), Climate Change, Justice and Sustainability, s.279; Patrick Bond ve Michael K. Dorsey, "Anatomies of Environmental Knowledge \& Resistance: Diverse Climate Justice Movements and Waning Eco-Neoliberalism”, Journal of Australian Political Economy, No.66, 2010, s.293; Mustafa Demirci, "İklim Değişikliği ve Dağıtıcı Adalet”, Eskişehir Osmangazi Üniversitesi İİBF Dergisi, Cilt 8, No.2, 2013, s.194-195.

16 Adaptasyon maliyetlerinin bölüşümünde, soruna sebep olma ve ödeme gücü konusundaki tartışmalar için bkz. Page, Climate Change, Justice and Future Generations, s.167-173; Ekolojik borç ve tarihsel sorumluluk konusundaki tartışmalar için bkz. Lukas H. Meyer ve Dominic Roser, "Climate Justice and Historical Emissions”, Critical Review of International Social and Political Philosophy, Cilt 13, No.3, 2010, s.233-234; Winfried Schneider, "Regional Dialogues on Climate Change and Justice: A Synthesis”, Ottmar Edenhofer et.al. (der), Climate Change, s.370.

17 Ikeme, "Equity, Environmetal Justice and Sustainability", s.202.

18 Joshi, “Environmental Justice Discourses”, s.680.

19 Shue, Climate Justice, s.6-7.

20 Joshi, “Environmental Justice Discourses”, s.680. 
sahiptir. ${ }^{21} \mathrm{Bu}$ farklılıklara bağlı çoklu adaletsizliklerle bütünleşen bir kavram olan iklim adaletine ilişkin alan yazınındaki tartışmalar da adaletin farklı boyutları ve bu boyutlara içkin olan talepler bağlamında önemli bir çeşitlilik göstermektedir.

\section{İklim Adaleti Hareketi}

İklim adaletine ilişkin tartışmaların sivil platformunu oluşturan İklim Adaleti Hareketi, gerek söylemi şekillendirmede gerekse bu söylemi resmi platformlara taşımada üstlendiği rolle söyleme içkin taleplerin belirlenmesi açısından önemli bir kaynaktır. 1980’lerde Birleşik Devletler'de patlak veren Çevresel Adalet Hareketi’nin ${ }^{22}$ bir uzantısı olarak ortaya çıkan İklim Adaleti Hareketi, küresel ölçekte oldukça geniş bir tabana yayılan, sadece iklim adaleti savunucularını değil, aynı zamanda doğa korumacıları, yerli halkları, neoliberal politika ve kapitalizm karşıtlarını da bünyesinde barından bir esnekliğe ve kapsayıcılığa sahiptir. ${ }^{23}$ İklim Adaleti Hareketi içinde yer alan gruplar yürüyüş, direniş, gösteri, protesto, toplantı vb. yöntemlerle iklim adaletsizliğine dikkat çekmeye, resmi müzakereleri etkilemeye ve hareketin talepleri ile uyumlu resmi ya da yasal çıktılar üretilmesini sağlamaya çalışırlar. $\mathrm{Bu}$ nedenle, bu türden organizasyonlar genellikle BMIDÇS Taraflar Konferanslarının (TK) hemen öncesinde ya da TK hazırlık toplantıları sürecinde yoğunlaşmaktır.

İklim Adaleti Hareketi, müzakereler nezdinde sesini ilk defa 2000 yılında Hollanda’nın Lahey kentinde yapılan 6. TK’ya paralel düzenlenen İklim Adaleti Zirvesi ile duyurmuştur. ${ }^{24}$ Daha sonra hemen hemen bütün TK toplantıları öncesinde (konferans çıtılarının eleştirisine yönelik olarak sonrasında da) geniş kapsamlı eylemler düzenlenmiştir. Bu eylemleri ayrı ayrı incelemek mümkün olmadığından, çalışmanın amacına uygun olarak İklim Adaleti Hareketi’ne ilişkin talepleri yansıtacak üç temel belge ele alınmıştır. Bunlar, 2002 Bali İklim Adaleti İlkeleri, 2010 Cochabamba Halklar Anlaşması ve 2013 Durban İklim Adaleti Diyaloğu Deklarasyonu'dur.

Bali İklim Adaleti ilkeleri, iklim değişikliğinin insan hakları ve çevresel adaletle olan bağlantısını ortaya koymak amacıyla, Kuzey ve Güney ülkelerinden bir grup sivil toplum kurumu tarafindan oluşturulan uluslararası bir koalisyonca hazırlanmış ve 2002 yılında Johannesburg'ta gerçekleşen Dünya Zirvesi’ne sunulmuştur. İlkeler Bildirgesi'nin ilk maddesi iklim adaletinin, tüm toplulukların iklim değişikliğinin etkilerinden ve çevresel bozulmanın diğer biçimlerinden uzak şekilde yaşama hakkına sahip olduğunu kabul etmesini ifade etmektedir. Bildirgede aynı zamanda iklim adaleti kapsamında yerli halkların temsil hakkına, şirketlerce desteklenen piyasa temelli çözümlerin reddedildiğine, gelişmiş ülkelerin gelişmekte olan ülkelere ekolojik borcuna ve bu borçla ilgili olarak kusursuz sorumluluğa tabi olmaları gerektiğine, kayıp ve zararın yine bu ülkelerce karşılanmasına

21 Okereke, "Climate Justice and the International Regime", s.464; James Goodman, "From Global Justice to Climate Justice? Justice Ecologism in an Era of Global Warming", New Political Science, Cilt 31, No.4, 2009, s.509.

22 Çevresel Adalet Hareketi, Birleşik Devletler'de atık boşaltım alanları ve kirletici endüstrilerin yer seçim kararlarındaki ırkçı eğileme yönelik protestolar neticesinde ortaya çıkmış, zaman içinde çevresel fayda ve zararın eşitsiz dağılımına dikkat çeken küresel bir hareket haline gelmiştir. Bkz. Robert D. Bullard, "Environmental Justice in The Twenty-first Century”, Robert D. Bullard (der), The Quest For Environmental Justice, San Francisco, Sierra Club Books, 2005, s.19- 22.

23 Fidelis Allen, “The State of The Climate Justice Movement in South Africa”, Capitalism Nature Socialism, Cilt 26, No.2, 2015, s.51; Paul Chatterton et.al., "Articulating Climate Justice in Copenhagen: Antagonism, The Commons, and Solidarity", Antipode, Cilt 45, No.3, 2013, s.606; Bond ve Dorsey, "Anatomies of Environmental Knowledge \& Resistance”, s.288.

24 Jetgro Pettit, “Climate Justice: A New Social Movement For Atmospheric Rights”, IDSBulletin, Vol.35, No.3, 2004, s.104. 
dikkat çekilmektedir. Bildirgeye göre iklim adaleti, doğanın ticarileştirilmesine ya da metalaştırılmasına karşı çıkmaktadır. Ayrıca iklim adaleti, yerli halkların kendi kültürlerinin, yaşamlarının, kaynaklarının ve kaderlerinin hâkimi olması gerektiğini vurgulamakta ve bu toplulukların öz belirlenim hakkını onaylamaktır. $^{25}$

İklim adaleti için verilen küresel mücadelede temel bir doküman olan Cochabamba Halklar Anlaşması ise, 2009 yılında Kopenhag'da gerçekleşen 10. TK'nın kırılgan nüfuslara yönelik daha güçlü bir koruma amaçlayan taraflar için hayal kırıklığı ile sonuçlanması neticesinde oluşturulmuştur. ${ }^{26}$ Kopenhag Mutabakatının hukuki bağlayıcılığa sahip olmaması, azaltım hedeflerinin yetersiz bulunması, anlaşmanın insan haklarına göndermede bulunmaması bu hayal kırıklığının başlıca nedenleridir. ${ }^{27}$ Konferansı takiben Bolivya Devlet Başkanı Eva Morales, 20-22 Nisan 2010 da Bolivya Cochabamba'da gerçekleşen “İklim Değişikliği ve Toprak Ananın Hakları Dünya Halkları Konferansı” için çağrıda bulunmuştur. 142 ülkeden 35.000’i aşkın kişinin katılımıyla gerçekleşen Konferans sonunda Cochabamba Halklar Anlaşması kabul edilmiştir. ${ }^{28}$

Anlaşma’nın hedefinde iklim değişikliğinin, çevresel bozulmanın, eşitsizliğin ve adaletsizliğin temel nedeni olarak görülen kapitalist sistem bulunmaktadır. Kapitalizme yönelik eleştiriler temelinde, doğayla uyumlu ve tüm yaşama saygılı yeni bir kalkınma modeli önerilmektedir. Halklar Anlaşması, tüm ülkelerin kendi halklarının temel ihtiyaçlarını karşılayacak bir üretim kapasitesine sahip olma hakkını kabul etmektedir. Ancak bu hak gelişmiş ülkelerin takip ettiği kalkınma çizgisini izlemek anlamına gelmemektedir. Halklar anlaşmasının vizyonu tarihsel ortak ancak farklılaşmış sorumluluk ilkesi üzerine temellenmektedir. Bu ilke gereğince gelişmiş ülkeler, sera gazı emisyonlarını ısı artışını $1^{\circ} C^{\prime}$ yi geçemeyecek şekilde sınırlandırmalıdır. Bu, atmosferdeki karbon yoğunluğunu 300 ppm'e indirecek bir sorumluluk yüklenmeleri gerektiği anlamına gelmektedir. Halklar Anlaşması'na göre gelişmiş ülkeler, tarihsel olarak atmosferin sera gazı emilim kapasitesini gelişmekte olan ülkelerin haklarını dikkate almaksızın, eşitsiz bir şekilde kullandıkları için bu ülkelere karşı ekolojik borçludurlar. Bu borcun karşılığında, emisyonlarını azaltarak gelişmekte olan ülkelerin kalkınmasına imkân sağlamak üzere atmosfer alanında yer açmalıdırlar. Ayrıca gelişmekte olan ülkelerin adaptasyon sorununa yönelik kapasite inşası için bu ülkelere teknolojik ve finansal kaynak sağlamalıdırlar. $\mathrm{Bu}$ amaçla bir adaptasyon fonu oluşturulmalı ve aynı zamanda kayıp ve zararlar için bir tazminat mekanizması geliştirilmelidir. Gelişmiş ülkeler yıllık olarak gelirlerinin \%6'sını gelişmekte olan ülkelerin iklim değişikliyle mücadelesine fon sağlamak amacıyla ayırmalıdır. Gelişmiş ülkeler ayrıca, iklim değişikliği nedeniyle yerlerinden olan halklar, göçmen ve mülteciler için yeni yerleşim alanları sağlamalı ve yeterli yaşam koşulları temin etmelidirler. Anlaşmada ayrıca, yerli halkların haklarına, yanlış çözümlerin yarattığı olumsuzluklara, gıda güveliğine, gıda güveliğinin sağlanmasında yerli halkların uygulamalarının önemine ve karar alma süreçlerine adil katılıma dikkat çekilmektedir.

25 "Bali Principles of Climate Justice“, http://www.corpwatch.org/article.php?id=3748, (Erişim Tarihi 10 Mart 2016).

26 Nicole Fabricant, "Good Living For Whom? Bolivia's Climate Justice Movement and The Limitations of Indigenous Cosmovisions”, Latin American and Caribbean Ethnic Studies, Cilt 8, No.2, 2013, s.169; Nicole Fabricant ve Kathryn Hicks, "Bolivia vs. The Billionaires: Limitations of The 'Climate Justice Movement' in International Negotiations", NACLA Report on Americas, Cilt 46, No.1, 2013, s.28; Bertie Russell et.al., "Movements and Moments for Climate Justice: From Copenhagen to Cancun Via Cochabamba”, ACME: An International E-Journal For Critical Geographies, Cilt 11, No.1, 2012, s.22.

27 Abate, "Public Nuisance Suits", s.249.

28 Bertie Russell et.al., "Movements and Moments for Climate Justice", s.23; Hans A. Baer, "The International Climate Justice Movement: A Comparison With The Australian Climate Movement”, The Australian Journal of Anthropology, Cilt 22, No.2, 2011, s.258. 
Anlaşmada son olarak toprak ananın haklarını güvece altına alan bir deklarasyonun kabul edilmesine ve Uluslararası Çevresel Adalet Mahkemesi'nin kurulmasına vurgu yapılmaktadır. ${ }^{29}$

Durban İklim Adaleti Diyaloğu ise 2011 yılında Güney Afrika Durban'da gerçekleşen 17. TK'da, Mary Robinson Vakfı ve DKE işbirliğiyle kurulmuştur. Diyalog 18 Eylül 2013'de İklim Adaleti Deklarasyonu'nu yayınlamıştır. Deklarasyon'da karar alma süreçlerine katılımın önemine dikkat çekilerek, özellikle etkilenen tarafların süreçte daha etkili olması gerektiği, yerli topluluklarının geleneksel uygulamaları ve tecrübeleri ile çözüm sürecinde öncü olabilecekleri fikri savunulmuştur. Deklarasyon'da üzerinde durulan ikinci konu, yeni bir kalkınma ya da büyüme rotasına ihtiyaç olduğudur. Fosil yakıtlardan arındırılmış yenilenebilir enerjiye dayalı daha sağlıklı ve adil bir büyümeye geçişin gerekli olduğu vurgulanmıştır. Deklarasyon'da gelecek nesillerin haklarına dikkat çekilerek, uzun vadeli kapasite inşasına ve direnç artırmaya yönelik yatırımlara yönelmenin gerekli olduğu belirtilmiştir. Ülkelerin azaltım ve adaptasyon konusunda sorumluluk yüklenmeleri gerektiği, tüm ülkelerin çözümün bir parçası olduğu ancak gelişmiş ülkelerin öncü bir rol oynamaları gerektiği ifade edilmiştir. Son olarak 2015 sonrası için adil, kararlı ve yasal açıdan bağlayıcı bir anlaşmaya olan ihtiyaç dile getirilmiştir. ${ }^{30}$

\section{İklim Rejimi Müzakereleri: BMiDÇS Taraflar Konferanslarında İklim Adaleti Tartışmaları}

Başta azaltım ve adaptasyon sorunları olmak üzere iklim adaletine ilişkin meseleler iklim müzakerelerinde her daim yoğun bir tartışma konusu olmuştur. Sera gazı emisyonlarının azaltımıyla ilgili yük paylaşımı sorunu, yani iklim adaletinin dağıtım boyutu 1992 BMİDÇS’nin 3 (1) maddesi ile büyük ölçüde çözüme kavuşturulmuştur. ${ }^{31} \mathrm{Bu}$ maddeye göre, "Taraflar, iklim sistemini, eşitlik temelinde ve ortak ancak farklı sorumluluklarına ve güçlerine uygun olarak, insanoğlunun günümüz ve gelecek kuşakların yararı için korumalıdır. Dolayısıyla, Taraflardan gelişmiş ülkeler iklim değişikliği ve onun zararlı etkileri ile savaşımda öncülük etmelidir." ${ }^{32}$ Ortak ancak farklılaşmış sorumluluk ilkesi iklim adaletiyle ilgili olarak iklim rejiminin merkezinde yer alan en önemli ilkedir.

İklim rejiminin gelişiminde önemli bir aşamayı ifade eden 1997 tarihli Kyoto Protokolü de azaltım yükümlügünün paylaşımında gelişmiş ve gelişmekte olan ülkeler arasında bir fark gözeterek Sözleşme'deki anlayışı sürdürmüştür. ${ }^{33}$ Kyoto Protokolü, bağlayıcı azaltım yükümlülükleri getirmesi ve ortak ancak farklılaşmış sorumluluğu temel alması bakımından iklim adaletinin talepleriyle uyuşan bir düzenleme olarak görülebilir. Ancak azaltım yükümlülüğünün $2^{\circ} \mathrm{C}$ hedefi için gerekli olanın çok

29 People’s Agreement of Cochabamba, https://pwccc.wordpress.com/2010/04/24/peoples-agreement/, (Erişim Tarihi 15 Mart 2016).

30 "Declaration on Climate Justice", http://www.wri.org/sites/default/files/declaration_on_climate_justice_0_0.pdf, (Erişim Tarihi 15 Mart 2016).

31 BMIDDÇS için bkz. http://unfccc.int/files/essential_background/background_publications_htmlpdf/application/ pdf/conveng.pdf, (Erişim Tarihi 15 Şubat 2016). Sözleşme metninin Türkçesi için bkz. http://www.csb.gov.tr/db/ iklim/webmenu/webmenu12421_1.pdf, (Erişim Tarihi 15 Şubat 2016).

32 BMIDÇS'de madde 3(1)'in dışında kişi başına emisyon ve tarihsel emisyon konularına Sözleşme'nin Önsözünde, Madde 3(2) ve Madde 2(4) ve (8)'de göndermede bulunulmuştur. Ortak ancak farklılaşmış sorumluluk ilkesine, gelişmiş ülkelerin sera gazı emisyonlarının azaltılmasında öncü olmalarına ve gelişmekte olan ülkelere finansal destek sağlamalarına ilişkin hükümler ise Madde 4 (1-10); 5(c) ve 7(b)'dir.

33 Kyoto Protokolü için bkz. http://unfccc.int/resource/docs/convkp/kpeng.pdf, (Erişim Tarihi 15 Şubat 2016). Protokol'ün Türkçesi için bkz. http://iklim.cob.gov.tr/iklim/Files/Mevzuat/kyoto_protokol.pdf, (Erişim Tarihi 15 Şubat 2016). 
daha altında kalması, Protokolde yer alan esneklik mekanizmalarının kırılgan ülkeler üzerinde olumsuz etkiler yaratması, teknoloji ve mali kaynakların transferine ilişkin kurumsal bir yapı sunmaması gibi sorunlar Protokolü iklim adaleti savunucularının ciddi eleştirisine maruz bırakmıştır.

İklim rejiminin gelişimindeki diğer önemli aşama ise 7-18 Aralık 2009 tarihlerinde Kopenhag'da gerçekleşen 15.TK ve Konferans sonunda kabul edilen Kopenhag Mutabakatıdır. Kopenhag Taraflar Konferansı iklim adaleti hareketinin en güçlü olduğu konferanslardan biridir. Konferans öncesinde yürütülen hazırlık çalışmalarıyla iklim adaleti söyleminin müzakerelere daha güçlü bir biçimde yansıtılmasına çalışılmış, aynızamanda Konferans boyunca süren AlternatifİklimZirvesi (Klimaforum09), yürüyüşler ve protestolarla bu etkinin canlı tutulması başarılmıştır. ${ }^{34}$ İklim adaleti hareketinin önemli isimlerinden Bolivya Devlet Başkanı Eva Morales'in iklim adaletine ilişkin olarak Konferans'ta yaptı̆̆ı etkileyici konuşma büyük bir yankı uyandırmıştır. ${ }^{35}$ Ancak Birleşik Devletler müzakere temsilcisi Todd Stern'in Kuzey'in iklim borcu sorumluğunu tanımasıyla ilgili olarak "suç ya da kabahat ya da tazminat anlamında bu sorumluluğu kesin olarak reddediyorum” ifadesi, sadece kirleten öder ilkesinin değil, aynı zamanda ortak ancak farklılaşmış sorumluluk ilkesinin de reddedildiğini ortaya koymuştur. ${ }^{36}$ Konferans sonunda ABD, Çin, Suudi Arabistan, Brezilya ve Hindistan'ın ortaklığıyla bir son dakika uzlaşısı olarak kabul edilen Mutabakat, bağlayıcı azaltım taahhütleri yerine gönüllü katkılar vurgusuyla Sözleşme’nin Kyoto sonrası dönemde izleyeceği yolu belirleyen bir dönüm noktası olmuştur.

2010 Meksika Cancun 16. TK ve 2011 Güney Afrika Durban 17. TK ise bağlayıcı anlaşma fikrinden giderek uzaklaşıldığı ve ülkelerin gönüllü katkıları üzerine inşa edilen yeni bir anlaşma fikrinin netleştiği toplantılardır. Durban'da alınan karar (TK 17/1) ile 2015’e kadar tamamlanıp 2020'de uygulanmaya başlanacak ve tüm taraflar için geçerli olacak Sözleşme altında bir protokol, başka bir hukuksal araç ya da hukuksal güce sahip çıtı niteliğinde yeni bir anlaşmanın hazırlanması kabul edilmiştir. Bu noktada belirtilmesi gereken önemli bir husus da bağlayıcı azaltım fikrinden uzaklaşılmasına rağmen, adaptasyon sorunun çok daha fazla dikkate alınmasıdır. Kopenhag'la beraber azaltım sorunuyla birlikte adaptasyon, müzakerelerin odağındaki temel sorun haline gelmiştir. ${ }^{37} \mathrm{Bu}$ amaçla Durban'da gelişmekte olan ülkelerin azaltım ve adaptasyon çabalarını desteklemek üzere Yeşil İklim Fonu oluşturmuş ve gelişmiş ülkelerin fona 2020'ye kadar yıllık 100 milyar dolar kaynak ayırması kararlaştırılmıştır. 2013 yılında Varşova’da gerçekleştirilen 19. TK'da ise kırılgan ülkelerin iklim değişikliğinin etkileriyle bağlantılı olarak uğradıkları kayıp ve zararın giderilmesi amacıyla Kayıp ve Zarar İçin Uluslararası Varşova Mekanizması kurulmuştur.

Yeni bir anlaşma kararının alındığı Durban'dan Paris’e kadar uzanan süreçte nasıl bir azaltım politikası izleneceği, yük paylaşımının hangi ilkeler üzerinden sağlanacağı, adaptasyon maliyetlerinin kimler tarafından karşılanacağı ve hangi gerekçelere dayandırılacağı önemli tartışma konuları olmuştur. Müzakerelerin iklim adaletine ilişkin konularda bu denli tartışmalı geçmesinin nedeni, kuşkusuz her devletin adaleti kendi bağlamında değerlendirmesi ve kendi öz çıkarına uygun bir adalet söylemini desteklemesidir. Bu doğal olarak müzakereler bağlamında adaletin farklı ve çatışan boyutlarını ya da yorumlarını gündeme getirmektedir.

34 Chatterton et.al., "Articulating Climate Justice in Copenhagen “, s.602-604; Baer, "The International Climate Justice Movement", s.257-258.

35 Fabricant ve Hicks, "Bolivia vs. The Billionaires”, s.28.

36 Bond ve Dorsey, “Anatomies of Environmental Knowledge \& Resistance”, s.287-288. Stern’in 2013 iklim müzakerelerindeki benzer bir konuşması için bkz. Tokar, "Democracy, Localism”, s.67-68.

37 Kelvin Mason ve Kye Askins, “COP 15 and Beyond: Politics, Protest and Climate Justice”, ACME: An International E-Journal For Critical Geographies, Cilt 12, No.1, 2013, s.20. 
R. Audet, Cancun müzakereleri kapsamında pazarlık koalisyonları üzerinden söylem analizi yapmış ve iklim adaletine ilişkin olarak sorumluluk, geçiş ve kırılganlık olmak üzere üç temel söylem belirlemiştir. Müzakerede azaltım ve adaptasyon maliyetlerini yüklenme anlamında sorumluluk söylemi en fazla ALBA (Latin Amerika için Bolivarcı İttifak) tarafından desteklenmiştir. Sorumluluk söylemini en az destekleyen grup ise BASIC’dir (Brezilya, Güney Afrika, Hindistan, Çin). Gelecek nesillere karşı sorumluluk ve harekete geçme sorumluğu üzerine inşa edilen geçiş söylemi (yeşil, düşük karbonlu ve sürdürülebilir bir ekonomiye geçiş) ise Avrupa Birliği (AB) ülkelerinin müzakere pozisyonunu temsil eden söylem olmuştur. Aciliyet ve hayatta kalma sorunlarına odaklanan kırılganlık söylemi ise AOSIS' in (Küçük Ada Devletleri) benimsediği söylemdir. Yaşam hakkı bağlamında hayatta kalma talebi, AOSIS’e göre ALBA’nın suçlu ve kurban diyalektiği üzerine temellen adalet söyleminden daha güçlü bir meşruiyet zemini sağlamaktadır. ${ }^{38}$

Paris müzakerelerinde koalisyonların benimsediği tutumlara baktı̆̆ımızda $A B$ ve Şemsiye Grubun $^{39}$ Sözleşme eklerine dayalı yük paylaşımının kaldırılmasını, azaltım ve finansman sorumluluğunun diğer taraflarla paylaşılmasını yani sorumluluk tabanın genişlemesini istedikleri söylenebilir. Bu görüşe en fazla karşı çıan grup ise Benzer Görüşteki Gelişmekte Olan Ülkeler Grubudur (LMDC).$^{40}$ Grup, ortak ancak farklılaşmış sorumluluk ilkesi ve tarihsel sorumluluklar konusundaki ısrarını sürdürmekte; azaltım özellikle de adaptasyon konusunda taahhüt üstlenmekten kaçınmaktadır. Konferansta yeni kurulan ittifakların odağında ise azaltım taahhütlerini yukarı çekmek bulunmaktır. Bu çerçevede en kırılgan ülkelerin oluşturduğu Kırılgan Ülkeler Formu (VCF - V20) ve VCF ülkelerinin de içinde yer aldığ $1,5^{\circ} \mathrm{C}$ ittifakından bahsedilebilir. Kanada, AB ülkeleri ve AILAC ${ }^{41}$ grubu üyeleri dâhil çok sayıda tarafın desteğini alan ittifakın müzakere öncelliklerine en büyük itiraz ise LMDC grubundan gelmiştir. Bu kapsamda değerlendirilebilecek bir başka ittifak ise Yüksek Kararlılık İttifakıdır. ${ }^{42}$

İklim değişikliği müzakerelerine ilişkin olarak gelişmekte olan ülkelerin talebinin, meseleyi emisyon azaltımı ile sınırlı tutmayan, sistemsel eşitsizliklerin giderilmesine yönelik daha geniş bir bağlama yerleştirmek olduğu, buna karşın gelişmekte olan ülkelerin ise emisyon azaltımı için ekonomik açıdan en etkin yolu bulmaya odaklandığı vurgulanmaktadır. ${ }^{43}$ Ancak Kyoto sonrası döneme yönelik müzakerelerde, koalisyonların sayısındaki artıştan da anlaşılacağı üzere gerilimin odağı KuzeyGüney ya da gelişmiş ve gelişmekte olan ülke şeklindeki klasik ayrımı aşmıştır. Hem gelişmiş hem de gelişmekte olan ülkelerin yapısal şartları gereği kendi içlerinde bölünmesi ve görüş ayrılıklarına düşmesi farklılaşan talepleri de beraberinde getirmiştir.

38 Audet, “Climate Justice and Bargaining Coalitions”, s.369-386. ALBA: Latin America Bolivarian Alternative; AOSIS: Alliance of Small Island States.

39 Şemsiye Grup, AB üyesi olmayan gelişmiş ülkeleri temsil etmektedir. Üyeleri arasında Amerika, Kanada, Norveç, Japonya ve Rusya sayılabilir.

40 Like Minded Group of Developing Countries (LMDC), aralarında bazı Latin Amerika, Afrika ve Asya ülkelerinin bulunduğu bir gruptur. Üyeleri arasında Çin, Hindistan, Suudi Arabistan, Bolivya, Venezuela, Mısır, Libya sayılabilir. LMDC'nin 8 Mart 2014 tarihli bildirimi için bkz. http://unfccc.int/files/documentation/submissions_from_parties/ adp/application/pdf/adp_lmdc_ws1_20140309.pdf, (Erişim Tarihi 18 Şubat 2016).

41 Bağımsız Latin Amerika ve Karayip İttifakı (Independent Alliance of Latin America and the Caribbean-AILAC). Üyeleri, Şili Kolombiya, Kosta Rika, Guatemala, Panama ve Peru'dur.

42 İttifakın içinde yer alan ülkeler, Küçük Ada Devletleri, En Az Gelişmiş Ülkeler, AILAC Ülkeleri, AB ve ABD’dir. Paris İklim Zirvesi'ne yönelik değerlendirmeler için bkz. Semra Cerit, “COP 21'de İkinci Hafta: Durban Platformundan Paris Komitesine”, https://murcir.marmara.edu.tr/notice/paris-iklim-zirvesinden-izlenimler-semra-cerit-cop21-deikinci-hafta-durban-platformundan-paris-komitesine/, (Erişim Tarihi 5 Şubat 2016); Semra Cerit, "Paris'te Sonbahar: Koalisyon İklimi”, https://murcir.marmara.edu.tr/notice/paris-iklim-zirvesinden-izlenimler-2-semra-cerit-paristesonbahar-koalisyon-iklimi/, (Erişim Tarihi 5 Şubat 2016).

43 Ikeme, "Equity, Environmetal Justice and Sustainability", s.200. 


\section{Çakışan ve Çatışan Talepler Bağlamında İklim Adaleti}

Daha öncede ifade edildiği üzere, iklim adaleti sadece iklim değişikliğinin orantısız etkilerine odaklanmamaktadır. İklim adaletinin çoklu adaletsizliklere temas etmesi, adaletin farklı boyutlarını gündeme getirmektedir. Doğal olarak iklim adaletine ilişkin talepler de adaletin farklı boyutlarına göre değişmektedir. Bu nedenle söyleme ilişkin talepleri, iklim adaletinin farklı boyutları üzerinden değerlendirmek daha doğru olacaktır.

Dağıtıcı Adalet: İklim adaletinin dağıtım boyutu, emisyon haklarının, azaltım yükümlülügünün ve hem azaltım hem de adaptasyon maliyetlerinin paylaşımı sorununa işaret etmektedir. Bu boyut kapsamında ön plana çıkan talepler, emisyon haklarının kişi başına tahsisi, azaltım yükümlülüğünün kirleten öder ilkesi gereği soruna sebep olmada en fazla paya sahip olan ülkelerce üstlenilmesi ve bu konuda tarihsel sorumlulukların dikkate alınmasıdır. Adaptasyon maliyetlerinin ise hem soruna katkı hem de kapasite (ödeme gücü) bağlamında paylaştırılmasıdır. ${ }^{44}$

Telafi Edici/Düzeltici Adalet: İklim adaletinin bu boyutu adaletsizliğin ve adaletsizlik sonucu ortaya çıkan zararın giderilmesini ifade etmektedir. Rawls'ın dağıtıcı adalete ilişkin olarak ortaya koyduğu fark ilkesi, en kötü durumda olanın şartlarını iyileştirmek üzere eşitsiz bir dağılımın meşru kabul edileceğine dikkat çekmektedir. ${ }^{45}$ Bu ilkeyle bağlantılı olarak iklim adaletinin bu boyutu da eşit şartlar yaratma ya da dengeleme talebi olarak düşünülebilir. Kırılgan toplulukların uğradığı kayıp ve zararın giderilmesi, adaptasyon maliyetlerinin karşılanması, temiz ve sürdürülebilir bir büyüme için teknolojik ve finansal destek sağlanması bu talebi karşılamanın başlıca yollarıdır. Bu adaletle bütünleşen bir başka talep de ülkelerin kırılganlığını daha da arttıran temiz kalkınma, karbon denkleştirme ve REDD gibi piyasa temelli çözümlerin terk edilmesidir.

Cezalandırıcı Adalet: Adaletin bu boyutu kirleten öder ilkesi, tarihsel sorumluluklar ya da ekolojik borç kapsamında iklim değişikliği sonucu ortaya çıkan kayıp ve zararın bedelinin ödenmesini ifade eder. Bu boyut endüstrileşmiş ülkelere bir tazminat sorumluluğu yüklemektedir. Tazminat talebi sadece sebep olunan somut kayıp ya da zarara ilişkin değildir, tarihsel emisyonlar neticesinde gelişmekte olan ülkelerin kalkınma firsatının ihlal edilmiş olmasının tazminatıdır. $\mathrm{Bu}$ nedenle finansal ve teknolojik kaynakların transferi yardım ya da bağış değil ekolojik borcun tazminatı olarak düşünülmelidir. ${ }^{46}$

Prosedürel Adalet: Adaletin bu boyutu adil olmayan bir süreçten adil sonuçlar çıkamayacağı savı üzerine temellenmektedir. Karardan etkilenen tüm tarafların karar alma sürecine dâhil olması ve iklim değişikliğinden en fazla zarar gören halkların sesinin müzakerelere daha fazla yansıması gerektiği talebini dile getirmektedir. ${ }^{47}$

Ekolojik Adalet: $\mathrm{Bu}$ adalet anlayışı, çevrenin ve doğal kaynakların insanlar arasında paylaşımından çok, insan ve doğal dünyanın geri kalanı arasındaki ilişkiye odaklanmaktadır. ${ }^{48}$ İklim adaleti hareketi içindeki Toprak Ananın Hakları talebi bu çerçeve içinde değerlendirilebilir. Doğayla uyumlu ve sürdürülebilir bir yaşam ise bir diğer önemli taleptir.

44 Bkz. Ibid., s.201; Page, Climate Change, Justice and Future Generations, s.167-17; Meyer ve Roser, "Climate Justice and Historical Emissions", s.233-234; People's Agreement of Cochabamba.

45 John Rawls, Halkların Yasası ve Kamusal Akıl Düşüncesinin Yeniden Ele Alınması, İstanbul, İstanbul Bilgi Üniversitesi Yayınları, 2006, s. xiv; Ikeme, "Equity, Environmetal Justice and Sustainability”, s.197.

46 Roberts ve Parks, A Climate of Injustice, s.164-165.

47 Ikeme, "Equity, Environmetal Justice and Sustainability", s.197.

48 Joshi, “Environmental Justice Discourses”, s 679. 
Nesiller Arası Adalet: Gelecek nesillerin yaşam hakkını güvence altına almaya odaklanan bu adalet anlayışı, sera gazı emisyonlarının en az $2^{\circ} \mathrm{C}$ hedefiyle uyumlu şekilde azaltımı ve fosil yakıtlardan arındırılmıss sürdürülebilir bir ekonomik kalkınma modelinin benimsenmesi taleplerini dile getirmektedir. ${ }^{49}$

Insan Hakkı Olarak Adalet: Bu adalet anlayışı, iklim değişikliğiyle bağlantılı etkileri bir insan hakkı sorunu olarak değerlendirmektedir. Bu boyut kapsamında dile getirilen başlıca talepler; sağlıklı ve yaşanabilir koşullar bağlamında güvenli bir çevre, yerli halklara öz belirlenim ve kaynak egemenliği haklarının sağlanması, temel ihtiyaçların karşılanması ve gıda güveliği, iklim mültecileri için sığınma koşullarının iyileştirilmesidir. ${ }^{50}$

Kalkınma Hakkı Olarak Adalet: Adaletin bu boyutu, temel ihtiyaçların karşılanması, yoksullukla mücadele ve eşitsizliklerin giderilmesi için gelişmekte olan ülkelerin kalkınma hakkını dile getirmektedir. Ayrıca bu adalet anlayışı gereğince endüstrileşmiş ülkeler küçül ve yaklaş (contraction and convergence) ilkesini hayata geçirerek, emisyonlarını azaltmalı ve gelişmekte olan ülkelerin kalkınması için atmosfer alanında yer açmalıdırlar. ${ }^{51}$

Hukuki Adalet: Adaletin bu boyutu, iklim değişikliğinden zarar gören tarafların haklarını koruyan ve güvence altına alan yasal düzenlemelerin önemine dikkat çekmektedir. Hukuki açıdan bağlayıcı yasal düzenlemelerin oluşturulması ve yasaların din, dil, ırk, cinsiyet ve sınıf farkı gözetmeksizin herkese eşit şekilde uygulanması bu adalet anlayışı çerçevesinde dile getirilen başlıca taleplerdir. ${ }^{52}$

Söz konusu taleplerin meşruluğunu ya da haklılığını tartışmak çalışmanın amacını aşmaktadır. Ancak yine de bazı taleplere ilişkin olarak öne sürülen eleştirileri dile getirmek önemlidir. İlk eleştiri, tarihsel sorumluklar ve buna bağlı tazminat talebine ilişkindir. Burada ileri sürülen temel sav, hiç kimsenin geçmiş nesillerin bilgisizlik ya da bilinçsizlik neticesinde yapmış olduğu eylemlerin sonuçlarından sorumlu tutulamayacağıdır. Bu sava ilişkin itiraz ise endüstriyel ülkelerin, geçmiş nesillerin kalkınma mirasını nasıl devraldılarsa bu kalkınma mirasının sorumluluğunu da aynı şekilde yüklenmeleri gerektiği yönündedir. ${ }^{53}$ İkinci bir eleştiri ise azaltım yükünün paylaşımına ilişkindir. Küresel karbondioksit emisyonunda en yüksek paya sahip olan 10 ülkenin 5’i Kyoto Protokolü’ne göre azaltım yükümlügü bulunan ülkeler listesinde (EK-B) yer almaktadır. ${ }^{54} \mathrm{Bu}$ nedenle yüksek emisyon oranlarına sahip Çin, Hindistan, Brezilya, Endonezya ve Suudi Arabistan gibi ülkelerin artık tarihsel emisyonlar ya da kişi başına emisyon hakları gerekçeleriyle azaltım yükümlülüğünün dışında kalamayacakları ileri sürülmektedir. Bu ülkelerin temel iddiası ise, dünyanın eşitsizlikler bakımından 1990’lardan daha farklı bir durum arz etmediği ve kişi başına emisyonlarda hâlâ gelişmiş ve gelişmekte olan ülkeler arasında

49 Audet, "Climate Justice and Bargaining Coalitions", s.377.

50 Joshi, “Environmental Justice Discourses”, s.680.

51 Ibid.; Rudolf Schüssler, "Climate Justice: A Question of Historic Responsibility”, Journal of Global Ethics, Cilt 7, No.3, 2011. s.262-263.

52 Margot Hurbert, “Climate Justice: A Call For Leadership”, Environmental Justice, Cilt 8, No.2, 2015, s.51-52; Ikeme, "Equity, Environmetal Justice and Sustainability”, s.197.

53 Ikeme, "Equity, Environmetal Justice and Sustainability", s.201.

54 Global Carbon Atlas, http://www.globalcarbonatlas.org/?q=en/emissions; Top 10 Emitters, http://www.wri.org/ blog/2014/11/6-graphs-explain-world\%E2\%80\%99s-top-10-emitters; The Largest Producer of CO2 Emissions Worldwide in 2015, http://www.statista.com/statistics/271748/the-largest-emitters-of-co2-in-the-world/; Each Country's Share of CO2 Emissions 2011, http://www.ucsusa.org/global_warming/science_and_impacts/science/ each-countrys-share-of-co2.html\#.VxiT-49OKM8, (Erişim Tarihi 12 Mart 2016). Veriler arası̄nda bazı farklar olmakla birlikte Çin, Amerika ve Hindistan karbon salınımı en fazla olan ilk üç ülkedir. 
çok ciddi farkların olduğudur. Üçüncü bir eleştiri ise kalkınma hakkı konusundadır. Öncelikle kalkınma hakkı, emisyon hakları bağlamında bir kirletme hakkı olarak görülmemelidir. İkincisi, yoksullukla mücadele, temel gereksinimlerin karşılanması, yaşam koşullarının iyileştirilmesi gibi amaçlarla talep edilen kalkınmanın olumlu etkilerinin, karbon emisyonu yüksek olan bu ülkelerde yoksul vatandaşların yaşamına yansımamasıdır. ${ }^{55} \mathrm{Bu}$ ülkelerde aşırı tüketime dayalı yaşam tarzlarıyla dikkat çeken ve giderek zenginleşen bir sınıfa karşılık, milyonlarca yoksul bulunmaktır. Dolayısıyla uluslararası talepler, ulusal düzeyde karşılığını bulmamaktadır. ${ }^{56}$ Greenpeace bu soruna dikkat çekmek üzere Hindistan'ın iklim politikalarına ilişkin raporunu "Yoksulların Arkasına Saklanmak" başlığıyla yayınlamıştır.

Roberts ve Parks ise emisyon ve kalkınma arasındaki ilişkinin adalet boyutunu daha farklı bir perspektiften değerlendirerek, bu ülkelerdeki yüksek salınımların emisyon ihracından ileri geldiğini ifade etmiştir. Roberts ve Parks’a göre, bu ülkelerde düşük ücretler, çevresel bozulma ve yüksek emisyonlar pahasına üretilen ürünler, Kuzey ülkeleri tarafından tüketilmektedir. ${ }^{58}$

Güney ülkelerinin savunmasının odağında ise kalkınmanın aslına temel bir adaptasyon stratejisi olduğu bulunmaktadır. Bu savı destekleyecek nitelikte ilginç sonuçlar ortaya koyan bir araştırma K. Running'in kırılganlık ile ekonomik kalkınma/çevre koruma önceliği ve ödeme isteği arasındaki ilişkiyi sorguladığı çalışmasıdır. ${ }^{59}$ Araştırma sonuçlarına göre kırılganlığı yüksek ülkeler, ekonomik kalkınmaya çevre korumadan daha fazla öncellik tanımaktadır. Bu ülkelerde yaşayan halklar için yoksullukla mücadele ve yaşam koşullarının iyileştirilmesi temel amaçtır. Kendi kalkınmaları üzerinde sınırlama getirecek iklim politikalarını adaletsiz bulurlar. Ancak ilginç bir biçimde bu ülkelerde ödeme isteği -kendi kişisel gelirlerinin bir bölümünü çevre koruma amaçna ayırabileceğini söyleyenlerin oranı- Kuzey ülkelerinden yüksektir. Örneğin, İklim Risk İndeksine göre kırılganlığı en yüksek ve ortalama gelir düzeyi en düşük ülkelerden biri olan Vietnam, ödeme isteği en yüksek olan ülke çıkmıştır. Dolayısıyla Running, bu ülkelerde ekonomik kalkınmaya öncellik tanınmasının, çevresel konulara ilişkin ilgi eksikliğinin ya da duyarsızlığın bir göstergesi olarak yorumlanamayacağını, bunun söz konusu ülkelerin çevresel sorunlar karşındaki direncini yükseltecek uzun vadeli bir strateji olarak düşünülmesi gerektiğini söylemektedir. ${ }^{60}$

\section{Paris Anlaşması ve İklim Adaleti}

BMIDDÇS kapsamında 2020 sonrası için ilkim değişikliğiyle mücadelenin ana hatlarını belirleyen Paris Anlaşması, 30 Kasım-11 Aralık 2015 tarihleri arasında Paris'te gerçekleşen 21. TK sonunda kabul edilmiş ve 22 Nisan 2016 da imzaya açılmıştır. ${ }^{61}$ Konferans öncesinde yaşanan terör saldırısı nedeniyle

55 Paul G. Harris et.al., "China and Climate Justice: Moving Beyond Statism”, International Environmental Agreements: Politics, Law, and Economics, Cilt 13, No.3, 2013, s.300-301; Joshi, "Environmental Justice Discourses”, s.683, 687-688.

56 Çin, Hindistan, Güney Afrika, Brezilya gibi ülkelerde, hatta iklim adaleti hareketinde özgün bir yere sahip olan Bolivya'da bile yerel halk, kendi hükümetlerini ulusal düzeyde iklim adaletini uygulamamakla eleştirmektedir. Bkz. Fabricant ve Hicks, "Bolivia vs. The Billionaires”, s. 28; Allen, “The State of The Climate Justice”, s.49, 52-53.

57 Joshi, "Environmental Justice Discourses”, s.682; Bkz. Karumanaseri N. Ananthapadmanabhan et al., Hiding Behind The Poor: A Report by Greenpeace on Climate Injustice, Greenpeace India Society, 2007. http://www.greenpeace.org/india/ Global/india/report/2007/11/hiding-behind-the-poor.pdf, (Erişim Tarihi 22 Mart 2016).

58 J. Timmons Roberts ve Bradley C. Parks, "Ecologically Unequal Exchange, Ecological Debt, And Climate Justice", International Journal of Comparative Sociology, Cilt 50, No.3-4, 2009, s.389, 392-393.

59 Katrina Running, “Towards Climate Justice: How Do The Most Vulnerable Weigh Environment-Economy TradeOffs?", Social Science Research, Cilt 50, 2015, s.217-228.

60 Ibid. s.225.

61 Paris Anlaşması için bkz. http://unfccc.int/files/essential_background/convention/application/pdf/english_paris_ agreement.pdf, (Erişim Tarihi 3 Şubat 2016). 
alınan yoğun güvenlik önlemlerine rağmen binlerce kişi Paris caddelerini doldurarak, iklim adaleti çağrısında bulunmuş ve etkili bir anlaşmanın eşitlik ve adalet ilkleri üzerine temellenmesi gerektiği görüşünü yinelemiştir. Bu durum dikkatleri Paris’ten çıkacak sonuç üzerine yoğunlaştırmış, yüksek beklentiler karşısında iklim adaletinin Paris Anlaşması'nda nasıl bir karşılık bulacağı merak konusu olmuştur.

İklim adaletiyle ilgili olarak, Paris Anlaşması ilk bakışta halefi olduğu Kyoto Protokolü’nden ya da BMIDDÇS'den farklı olarak, insan hakları, yerli halkları, kırılgan ülkeler, iklim adaleti, toprak ana gibi kavramlara yer vermesi bakımından bu yöndeki kaygıları daha fazla dikkate aldığı yönünde bir yoruma neden olabilmektedir. Ancak Anlaşma metni biraz daha dikkatli değerlendirildiğinde, iklim adaletine ilişkin kaygıların sadece retorik düzeyde kaldığını düşündürecek çok fazla sorun olduğu görülmektedir.

Öncellikle Anlaşma’nın pek çok konuda netlik taşımadığı, kararlı ve açık hükümlerden ziyade genel bir çağrı niteliği taşıyan, belirsiz ve muğlak hükümler içerdiği belirtilmelidir. Ayrıca iklim adaletiyle ilgili birçok maddenin içeriğini dolduracak şartların sonraya, Paris Anlaşması́nın ilk TK'sında alınacak kararlara bırakıldığı görülmektedir. Aslında Paris Anlaşması'na ilişkin müzakereler 2011'de Durban'da alınan karar TK17/1 ile başlamıştır. Ancak son dakikaya kadar Paris'te bir anlaşmaya varılıp varılamayacağı sorusu belirsizliğini korumuştur. $\mathrm{Bu}$ belirsizlik ve tartışma ortamından son dakika uzlaşısı olarak ortaya çıkan sonuç, zorunlu ve kapsamlı davranış değişiklikleri getirmeyen bir anlaşma olmuştur. Paris Anlaşması'nın temel zayıflı̆̆, Anlaşma’nın amacı ile bu amaca ulaşmak için üzerinde anlaşılan ölçütler arasındaki derin uçurumdur. ${ }^{62} \mathrm{Bu}$, iklim aktivisitlerinin, iklim adaleti savunucularının hatta iklim bilimcilerinin Anlaşmayı, sahtekârlık, saçmalık gibi kavramlarla nitelendirmesinin de başlıca nedenidir. ${ }^{63}$

Paris Anlaşması bir önceki kısımda tanımlanan iklim adaleti talepleri doğrultusunda biraz daha ayrıntılı değerlendirildiğinde, anlaşma dilinin yarattı̆̆ ilk yanılsama da büyük ölçüde ortadan kaybolmaktadır. Dağıtıcı adalete ilişkin olarak Paris Anlaşması, emisyon haklarının değil, azaltım sorumluluğunun paylaşımı üzerinden işlemektedir. Gerek alan yazını gerekse hareket içinde tartışmalı bir konu olan kişi başına emisyon hakkıyla ilgili Anlaşma'da her hangi bir ifade bulunmamaktadır. Azaltım sorumluluğunun paylaşımında kirleten öder, tarihsel sorumlulukgibi dağıtıcıadaletin odağında yer alan ilke ve yaklaşımlara da yer verilmemektedir. Paris Anlaşması’nda azaltım sorumluğunun ve adaptasyon maliyetlerinin paylaşımına rehber olan ilkeler, eşitlik ve ulusal koşullar ışığında ortak ancak farklılaşmış sorumluluk ve göreli kapasite ilkeleridir. Ancak azaltım sorumluğu ve adaptasyon maliyetlerinin tahsisiyle ilgili olarak BMİDÇS'de benimsenen eklere herhangi bir göndermede bulunulmamaktadır. Anlaşmanın 3. Maddesine göre, tarafların tamamı anlaşmanın amacına ulaşmayı sağlayacak çabaları üstlenmekle sorumludur. Bu şartlar altında farklılaşmaya ilişkin tek kıstas muğlak ve yoruma açık bir nitelik taşıyan ulusal koşular olmaktadır. Bununla birlikte Anlaşma'da gelişmekte olan ülkelerin anlaşmayı etkin şekilde uygulamaları yönünden desteklenmelerine [Madde 3 ve 4(5)] ve emisyon azaltımında gelişmiş ülkelerin öncü olmaya devam etmesine [Madde 4(4)] ilişkin hükümler bulunmaktadır.

Telafi edici/düzeltici adalet boyutuna ilişkin kaygılara ise özellikle Anlaşma’nın Önsözünde dikkat çekilmektedir. Bu kısımda, gelişmekte olan ülke Tarafların, özellikle kırılgan ülkelerin, özgül

62 Paris Anlaşması küresel ısınmayı $2{ }^{\circ} \mathrm{C}$ 'nin çok altında ve mümkünse $1,5{ }^{\circ} \mathrm{C}$ ile sınırlandırmayı amaçlamaktadır. Oysa tarafların ulusal katkı beyanlarındaki taahhütleri yaklaşık olarak 3,5-4 ${ }^{\circ} \mathrm{C}^{\prime}$ lik bir ısı artışına tekabül etmektedir.

63 Brian Tokar, “The Paris Climate Agreement: Hope or Hype?”, http://www.parisclimatejustice.org/article/parisclimate-agreement-hope-or-hype, (Erişim Tarihi 30 Mart 2015). 
ihtiyaçlarının ve özel koşullarının tanındığı; bu ülkelerin aynı zamanda çözüm politikalarından da zarar görebileceğinin kabul edildiği ve en az gelişmiş ülkelerin fon ve teknoloji transferiyle ilgili özgül ihtiyaçlarının ve özel koşullarının dikkate alındığı ifadelerine yer verilmektedir. Ayrıca Anlaşma’nın 7. Maddesi'nde düzenlenen adaptasyon ihtiyacına yönelik hükümler çerçevesinde, gelişmekte olan ülkelere sürekli ve artan uluslararası destek sağlanacağı ifade edilmektedir [Madde 7(13)]. Finansmanla ilgili olarak Madde 9(1)'de “Gelişmiş ülkeler Sözleşme kapsamındaki yükümlülüklerinin bir uzantısı olarak, azaltım ve adaptasyon eylemlerinde gelişmekte olan ülkeleri desteklemek için finansal kaynak sağlayacaktır” denmektedir. Benzer bir hüküm Madde 10(5) de teknoloji transferi ve Madde 11(3) de kapasite inşası için yinelenmektedir. Gelişmekte olan ülkelere sağlanacak mali destek kapsamında Sözleşme’nin finansman mekanizmasının, Anlaşma’nın finansman mekanizması olarak işlev göreceği kabul edilmektedir. Ayrıca finansal katkılara ilişkin olarak karar TK21/53 uyarınca yıllık 100 milyar ABD doları taban olmak üzere yeni bir ortak tutar belirlenmesi kararlaştırılmıştır. ${ }^{64}$ Finansman mekanizmalarının etkin olmadığı ve hedeflenen finansal katkılara ulaşılmadığı bilinmekle beraber, bu oranın Halklar Anlaşmasında öngörülen tutarın (gelirlerinin \%6’sı) çok altında (yaklaşık $\% 0,05$ ’i) olduğu görülmektedir. ${ }^{65}$

Telafi edici/düzeltici adalet kapsamındaki taleplerin bir boyutu da daha öncede ifade edildiği üzere piyasa mekanizmasına dayalı çözümlere odaklanmaktadır. Anlaşma'nın önsözünde çözüm önlemlerinden zarar görebilecek tarafların olabileceği kabul edilmekte ve Madde 4(15)'de söz konusu tarafların kaygılarının göz önünde bulundurulacağı ifade edilmektedir. Bununla birlikte Anlaşma’nın 5. Maddesi'nde iklim adaleti söylemi çerçevesinde ciddi eleştirilere konu olan, ormansızlaşmadan ve orman alanlarının bozulmasından kaynaklanan emisyonların azaltılmasına yönelik çabaların teşvik edilmesinin önemine dikkat çekilmektedir. Madde 6(4)'de sera gazı emisyonlarının azaltılması ve sürdürülebilir kalkınmanın desteklenmesi amacıyla kurulması kararlaştırılan mekanizma ise hükümlerdeki belirsizliğe rağmen temiz kalkınma mekanizmasına benzer bir piyasa mekanizmasını çağrıştırmaktadır.

Cezalandırıcı adalet kapsamında değerlendirilen talepler ise Paris Anlaşması́nda herhangi bir karşılık bulmamaktadır. Anlaşma, "Kayıp ve Zarar İçin Varşova Uluslararası Mekanizması”nı temel almaktadır. Madde 8(3)'e göre, "iklim değişikliğine bağlı kayıp ve zararlarla ilgili olarak Taraflar, Varşova Mekanizması vasıtasıyla işbirlikçi ve kolaylaştırıcı bir temelde anlayış, eylem ve desteği arttırmalıdırlar." Ancak karar TK21/51'de Anlaşma'nın 8. Maddesi'nin herhangi bir sorumluluk ve ya tazminatla ilgili olmadığı ve ya herhangi bir sorumluluk ya da tazminata temel teşkil etmediği belirtilmektedir. Bu karar, iklim adaletinin merkezinde yer alan ekolojik borcun reddedildiğini göstermektedir.

Anlaşma’nın prosedürel adalete ilişkin şartların sağlandığı bir süreç neticesinde ortaya çıktığını söylemek de güçtür. İklim rejimine ilişkin müzakereler her daim taraflar arasındaki güç dengesinden etkilenmiştir. Ayrıca güçlü çıkar gruplarının hükümetler üzerindeki etkisi de iklim değişikliğinden en fazla zarar gören kırılgan ülkelerin müzakerelerde yeterli temsil fırsatına sahip olmasını ve seslerini duyurabilmelerini etkilemiştir.

Ekolojik adaletle ilgili olarak ise Paris Anlaşması́nın önsözündeki "okyanuslarda dâhil tüm ekosistemlerin bütünlüğünün güvenceye alınması, bazı kültürlerin Toprak Ana olarak adlandırdığı

64 BMİDÇS 21.TK'da alınan kararlar için bkz. http://unfccc.int/resource/docs/2015/cop21/eng/10a01.pdf, (Erişim Tarihi 3 Şubat 2016).

65 "Comparison of the People's Agreement and the Copenhagen Accord", https://pwccc.wordpress.com/2010/06/16/ comparision-of-the-people\%C2\%B4s-agreement-and-the-copenhagen-accord/, (Erişim Tarihi 3 Nisan 2016). 
biyoçeşitliliğin korunması" ifadesi temel alınabilir. Ancak bu ifadeye yer verilmiş olması tek başına, ekosistemlerin ve toprak ananın haklarının tanındığıve güvence altına alındığı anlamına gelmemektedir. Dahası Anlaşma, insan ve doğa arasındaki ilişkiye de her hangi bir göndermede bulunmamaktadır.

Nesiller arası adalet boyutuna ilişkin talepler ise genel olarak anlaşmanın amacıyla uyumlu görünmektedir. Isı artışını $2^{\circ} \mathrm{C}$ 'nin altında tutarak, $1,5^{\circ} \mathrm{C}$ hedefine yönelik çaba gösterilmesi yönündeki karar ve sürdürülebilir kalkınma ile düşük emisyonlu büyüme vurgusu, nesiller arası adalet taleplerine temel teşkil etmektedir. Ancak ısı artışı için belirlenen hedefin iklim adaletinin $1^{\circ} \mathrm{C}$ hedefiyle uyuşmaması, diğer taraftan beyan edilen ulusal katkıların bu hedefin çok daha üstünde bir ısı artışına neden olacak olması, bu adalet talebinin de aslında karşılanmadığını göstermektedir.

İnsan haklarıyla ilgili konulara da yine Anlaşma’nın Önsözünde yer verilmiştir. Önsözde yer alan hükme göre:

Taraflar iklim değişikliyle mücadeleye yönelik eylemlerinde insan hakları, sağlık hakkı, yerli halkların, yerel toplulukların, göçmenlerin, çocukların, engellilerin ve hassas durumdaki kişilerin hakları, kalkınma hakkı ve cinsiyetler arası eşitlik, kadınların güçlendirilmesine ve kuşaklar arası adalet konularındaki yükümlülüklerine uygun hareket etmeli, bu hususlara saygılı olmalı ve onları geliştirmelidirler. ${ }^{66}$

Her biri ayrı hassasiyet gerektiren birçok hakkın topyekûn tek bir hüküm içinde eritilmesi ve söz konusu hükmün bağlayıcılığı tartışmalı olan önsözde yer alması, insan hakları konusunda yeterli güvence sağlanamadığını göstermektedir.

Kalkınma hakkı da yukarıdaki hükümde geçmektedir. Bununla birlikte yoksullukla mücadele ve sürdürülebilir kalkınma kavramaları anlaşma bütününde sıkça vurgulanmaktadır. Ancak iklim adaleti çerçevesinde kalkınma hakkı ile bütünleşen emisyon hakkı, gelişmiş ülkelerin atmosfer alanından çekilmesi ve böylelikle gelişmekte olan ülkelere kalkınma fırsatı sağlamaları, ekolojik borçları kapsamında bu ülkelerin kalkınmasına destek olmaları gibi talepleri içeren bir kalkınma hakkı anlayışı Anlaşma'da yer almamaktadır.

Paris Anlaşması hukuki adalet çerçevesinde değerlendirildiğinde öncellikle bağlayıcılık sorununa işaret edilmesi gerekmektedir. Paris Anlaşması aslında hukuki açıdan bağlayıcı bir düzenlemedir. Ancak sera gazı emisyonlarının azaltımına ilişkin taraflar açısından bağlacı sonuç doğuran bir yükümlülüğe yer vermemektedir. Taraflar, azaltım konusundaki katkı hedeflerini ulusal koşuları temelinde kendileri belirlemektedir. Diğer bir ifadeyle, Anlaşma zorunlu ve bağlayıcı azaltım hedefleri yerine, tarafların gönüllü katkıları üzerinden işlemektedir. Bununla birlikte Anlaşma’da yer alan yükümlülüklerin yerine getirilmemesi ya da Anlaşma hükümlerinin ihlal edilmesi durumunda, ilgili taraf ya da taraflara uygulanacak yaptırıma dair bir hüküm bulunmamaktadır. Anlaşmaya uygunluğun sağlanmasında Madde 13(1) uyarınca oluşturulan Şeffaflık Çerçevesinden bahsedilebilir. Şeffaflık Çerçevesi, tarafların Anlaşma'nın amacına ulaşmak için hem emisyon azaltımına hem de adaptasyona yönelik olarak yürüttüğü faaliyetlerin bildirimini içermektedir. Tarafların bildirimi teknik uzman incelemesine tabi olmakla birlikte, Madde 13(3)'de Çerçeve'nin işleyişiyle ilgili olarak, "kolaylaştırıcı, zorlayıcı ve cezalandırıcı olmayan bir tarzda, ulusal egemenliğe saygılı biçimde ve Taraflar üzerinde aşırı yük oluşturulmasını önleyecek şekilde uygulanması” ifadesine yer verilmiştir. Bu kapsamda uyum sorunu olan taraflara her hangi bir zorlayıcı tedbir öngörülmemiştir. Uyuşmazlıkların çözümü

66 Paris Agreement, http://unfccc.int/files/essential_background/convention/application/pdf/english_paris_agreement. pdf (Erişim Tarihi 3 Şubat 2016). 
konusunda ise Paris Anlaşması, Sözleşme'nin 14. Maddesinde tanımlanan ve uyuşmazlığın barışçıl yollardan çözümünü ifade eden bir prosedür benimsemektedir. Kısacası anlaşmanın bağlayıcılığı, kırılgan toplulukların haklarını koruyacak bir niteliğe sahip değildir. Anlaşmaya uygunluğun sağlanması büyük ölçüde tarafların inisiyatifine ve iyi niyetine bırakılmıştır.

\section{Sonuç}

İklim değişikliğiyle mücadeleye yönelik olarak BMİDÇŞ çatısı altında 20 yılı aşkın süredir devam eden müzakerelerin, sera gazı emisyonlarını sınırlamada ve iklim değişikliğinden zarar görenlerin haklarını korumada başarıya ulaştı̆̆ını söylemek güçtür. Sorunun aciliyetinin her geçen gün artması ve iklim değişikliğinin etkilerinin giderek daha yıkıcı hale gelmesi, bu konuda etkin çözümlere olan ihtiyacı baki kılmaktadır. Paris Anlaşması bu açıdan büyük umutlarla beklenen, önemli bir fırsat olarak görülmüştür.

Ne var ki, uluslararası rejimlerin inşasına yönelik müzakereleri ulusal çıkarların ötesine taşımak güçtür. Karşılıklı olarak hak ve yükümlülüklerin tanınması, bireysel faydanın artırılması ve işlem maliyetlerinin düşürülmesi gibi amaçları aşan, etik ilkeler temelinde tarafların bir takım sorumluluklar yüklenmesini sağlayan bir uluslararası müzakere sürecinin tesis edilmesi, egemen ve rasyonel aktörler olarak ulus devletleri temel alan ve devletler arasındaki güç dengesine göre işleyen bir uluslararası sistemde başarılması zor bir iştir. Ancak uluslararası müzakerelerde, bir bütün olarak uluslararası toplumun çıkarlarını ulusal çıarlara feda etmek meşru bir durum değildir. Gezegen üzerinde yaşayan milyonlar insanın yaşamını hatta var oluşunu tehdit eden bir meseleye, sınırlı ulusal çıkarlar bağlamında ekonomik verimlilik perspektifinden yaklaşmak, risk ve fayda-maliyet analizleri üzerinden çözüm üretmek, belirsizlikleri eylemsizlik için gerekçeye dönüştürmek sorunu çözümsüz bırakmaktadır. $\mathrm{Bu}$ nedenle iklim değişikliğini aynı zamanda etik bir sorun olarak görmek ve tartışmak önemli bir adımdır. Bu etik açılımı sağlama açısından iklim adaleti oldukça güçlü bir zemin sağlamaktadır. Paris Anlaşması müzakereleri bu anlamda meseleyi daha farklı bir perspektiften ele almak ve iklim rejiminde temel bir dönüşüm başlatmak için önemli bir firsat sunmuştur. Bu firsatın etkin bir biçimde değerlendirildiği söylemekse güçtür. İklim adaletine ilişkin kaygıları dikkate alma konusunda Paris Anlaşması retoriğin ötesine geçememiştir. İklim adaletine ilişkin kaygılara anlaşma metninde yer verilmesi, eyleme yönelik politikalara zemin oluşturmamıştır. Ancak Paris anlaşması bağlayıcı düzenlemeler yerine, gönüllülüğü temel alan düzenlemeleri benimseyerek, farklı bir alanda temel bir dönüşüm gerçekleştirmiştir. $\mathrm{Bu}$ çerçevede, gönüllü çabaların iklim adaleti anlamında etkin sonuçlar üretip üretmeyeceğini ise zaman gösterecektir. 


\section{Kaynakça}

Abate, Randall S. "Public Nuisance Suits For The Climate Justice Movement: The Right Thing and The Right Time”, Washington Law Review, Cilt 85, No.2, 2010, s.197-252.

Allen, Fidelis. "The State of The Climate Justice Movement in South Africa”, Capitalism Nature Socialism, Cilt 26, No.2, 2015, s.46-57.

Ananthapadmanabhan, Karumanaseri N. et.al. Hiding Behind the Poor: A Report By Greenpeace on Climate Injustice, Greenpeace India Society, 2007, http://www.greenpeace.org/india/Global/india/report/2007/11/ hiding-behind-the-poor.pdf, (Erişim Tarihi 22 Mart 2016).

Audet, René. "Climate Justice and Bargaining Coalitions: A Discourse Analysis", International Environmental Agreements: Politics, Law and Economics, Cilt 13, No.3, 2013, s.369-386.

Baer, Hans A. "The International Climate Justice Movement: A Comparison With The Australian Climate Movement", The Australian Journal of Anthropology, Cilt 22, No.2, 2011, s.256-260.

"Bali Principles of Climate Justice", http://www.corpwatch.org/article.php?id=3748, (Erişim Tarihi 10 Mart 2016).

"Birleşmiş Milletler İklim Değişikliği Çerçeve Sözleşmesi", http://www.csb.gov.tr/db/iklim/webmenu/ webmenu12421_1.pdf, (Erişim Tarihi 15 Şubat 2016).

Bond, Patrick ve Michael K. Dorsey. "Anatomies of Environmental Knowledge \& Resistance: Diverse Climate Justice Movements and Waning Eco-Neoliberalism”, Journal of Australian Political Economy, No.66, 2010, s.286-316.

Bullard, Robert D. "Environmental Justice in The Twenty-first Century", Robert D. Bullard (der), The Quest For Environmental Justice, San Francisco, Sierra Club Books, 2005.

Cerit, Semra. “COP 21'de İkinci Hafta: Durban Platformundan Paris Komitesine”, https://murcir.marmara.edu. tr/notice/paris-iklim-zirvesinden-izlenimler-semra-cerit-cop21-de-ikinci-hafta-durban-platformundanparis-komitesine/, (Erişim Tarihi 5 Şubat 2016).

Cerit, Semra, "Paris'de Sonbahar: Koalisyon İklimi”, https://murcirmarmara.edu.tr/notice/paris-iklimzirvesinden-izlenimler-2-semra-cerit-pariste-sonbahar-koalisyon-iklimi/, (Erişim Tarihi 5 Şubat 2016).

Chatterton, Paul vd. "Articulating Climate Justice in Copenhagen: Antagonism, The Commons, and Solidarity", Antipode, Cilt 45, No.3, 2013, s.602-620.

"Climate Change 2014: Synthesis Report", Geneva, Switzerland, IPCC, 2015.

"Comparison of the People's Agreement and the Copenhagen Accord", https://pwccc.wordpress. com/2010/06/16/comparision-of-the-people\%C2\%B4s-agreement-and-the-copenhagen-accord/, (Erişim Tarihi 3 Nisan 2016).

"Declaration on Climate Justice“, http://www.wri.org/sites/default/files/declaration_on_climate_ justice_0_0.pdf, (Erişim Tarihi 15 Mart 2016).

Demirci, Mustafa, “İklim Değişikliği ve Dağıtıcı Adalet”, Eskişehir Osmangazi Üniversitesi İİBF Dergisi, Cilt 8, No.2, 2013, s.183-203.

Each Country's Share of CO2 Emissions 2011, http://www.ucsusa.org/global_warming/science_and_ impacts/science/each-countrys-share-of-co2.html\#.VxiT-49OKM8, (Erişim Tarihi 12 Mart 2016).

Fabricant, Nicole ve Kathryn Hicks. "Bolivia vs. The Billionaires: Limitations of The 'Climate Justice Movement' in International Negotiations”, NACLA Report on Americas, Cilt 46, No.1, 2013, s.27-31.

Fabricant, Nicole. " Good Living For Whom? Bolivia's Climate Justice Movement and The Limitatitions of Indigenous Cosmovisions", Latin American and Caribbean Ethnic Studies, Cilt 8, No.2, 2013, s.159-178.

Forsyth, Tim. “Climate Justice Is Not Just Ice”, Geoforum, Cilt 54, 2014, s.230-232.

Global Carbon Atlas, http://www.globalcarbonatlas.org/?q=en/emissions, (Erişim Tarihi 12 Mart 2016). 
Goodman, James. “From global Justice to Climate Justice? Justice Ecologism in an Era of Global Warming”, New Political Science, Cilt 31, No.4, 2009, s.499-514.

Harris, Paul G.vd. "China and Climate Justice: Moving Beyond Statism”, International Environmental Agreements: Politics, Law, and Economics, Cilt 13, No.3, 2013, s.291-305.

Hurbert, Margot, “Climate Justice: A Call For Leadership”, Environmental Justice, Cilt 8, No.2, 2015, s.51- 55.

Ikeme, Jewku. "Equity, Environmental Justice and Sustainability: Incomplete Approaches in Climate Change Politics", Global Environmental Change, Cilt 13, No.3, 2003, s.195-206.

Joshi, Shangrila. "Environmental Justice Discourses in Indian Climate Politics", GeoJournal, Cilt 79, No.6, 2014, s.677-691.

Knopf , Brigitte vd. "A Global Carbon Market and The Allocation of Emission Rights", Ottmar Edenhofer vd. (der), Climate Change, Justice and Sustainability, Dordrecht, Springer, 2012.

Kreft, Sönke ve David Eckstein. Global Climate Risk Index 2014, Berlin, Germanwatch, 2013.

"Kyoto Protocol to the United Nations Framework Canvention on Climate Change", http://unfccc.int/ resource/docs/convkp/kpeng.pdf, (Erişim Tarihi 15 Şubat 2016).

"Kyoto Protokolü”, http://iklim.cob.gov.tr/iklim/Files/Mevzuat/kyoto_protokol.pdf, (Erişim Tarihi 15 Şubat 2016).

Luo, Tionyi vd. "World's 15 Countries With the Most People Exposed to River Floods", http://www.wri.org/ blog/2015/03/world\%E2\%80\%99s-15-countries-most-people-exposed-river-floods, (Erişim Tarihi 22 Şubat 2016).

Mason, Kelvin ve Kye Askins. "COP 15 and Beyond: Politics, Protest and Climate Justice", ACME: An International E-Journal For Critical Geographies, Cilt 12, No.1, 2013, s.9-22.

Meyer, Lukas H. ve Dominic Roser. "Climate Justice and Historical Emissions", Critical Review of International Social and Political Philosophy, Cilt 13, No.3, 2010, s.229-253.

Moellendorf, Darrel. “Climate Change Justice”, Philosophy Compass, Cilt 10, No.3, 2015, s.173-186.

Okereke, Chukwumerije. "Climate Justice and the International Regime", Wiley Interdisciplinary Reviews: Climate Change, Cilt 1, No.3, 2010, s.462-474.

Page, Edward A. Climate Change, Justice and Future Generations, Cheltenham UK, Edward Elgar Publishing, 2006.

"Paris Agreement", http://unfccc.int/files/essential_background/convention/application/pdf/english_ paris_agreement.pdf, (Erişim Tarihi 3 Şubat 2016).

People's Agreement of Cochabamba, https://pwccc.wordpress.com/2010/04/24/peoples-agreement/ (Erişim Tarihi 15 Mart 2016).

Pettit, Jetgro. “Climate Justice: A New Social Movement For Atmospheric Rights” , IDSBulletin, Vol 35, No.3, 2004, s.102-106.

Popp, Alexander vd. "Mechanisms For Avoiding Deforestation and Forest Degradation”, Ottmar Edenhofer vd. (der), Climate Change, Justice and Sustainability, Dordrecht, Springer, 2012.

Rawls, John. Halkların Yasası ve Kamusal Akıl Düşüncesinin Yeniden Ele Alınması, İstanbul, İstanbul Bilgi Üniversitesi Yayınları, 2006.

Reese, Gerhard. "Common Human İdentity and the Path to Global Climate Justice", Climatic Change, Cilt 134, No.4, 2016, s.521-531.

Roberts, J. Timmons ve Bradley C. Parks. "Ecologically Unequal Exchange, Ecological Debt, And Climate Justice", International Journal of Comparative Sociology, Cilt 50, No.3-4, 2009, s.385-409.

Roberts, J. Timmons ve Bradley C. Parks. A Climate of Injustice: Global Inequality, North-South Politics, and Climate Policy, Cambridge, MIT Press, 2007.

Running, Katrina. “Towards Climate Justice: How Do The Most Vulnerable Weigh Environment-Economy Trade-Offs?”, Social Science Research, Cilt 50, 2015, s.217-228. 
Russell, Bertie vd. "Movements and Moments for Climate Justice: From Copenhagen to Cancun Via Cochabamba”, ACME: An International E-Journal For Critical Geographies, Cilt 11, No.1, 2012, s.15-32.

Schneider, Winfried. "Regional Dialogues on Climate Change and Justice: A Synthesis", Ottmar Edenhofer vd. (der), Climate Change, Justice and Sustainability, Dordrecht, Springer, 2012, s.361-372.

Schüssler, Rudolf. "Climate Justice: A Question of Historic Responsibility”, Journal of Global Ethics, Cilt 7, No.3, 2011, s.261-278.

Shue, Henry. Climate Justice: Vulnerability and Protection, Oxford, Oxford University Press, 2014.

The Largest Producer of CO2 Emissions Worldwide in 2015, http://www.statista.com/statistics/271748/thelargest-emitters-of-co2-in-the-world/, (Erişim Tarihi 12 Mart 2016).

Tokar, Brain. "Democracy, Localism, and The Future of The Climate Movement", World Futures, Cilt 71, No.34, 2015, s.65-75.

Tokar, Brian. "The Paris climate agreement: hope or hype?", http://www.parisclimatejustice.org/article/parisclimate-agreement-hope-or-hype, (Erişim Tarihi 30 Mart 2015).

Top 10 Emitters, http://www.wri.org/blog/2014/11/6-graphs-explain-world\%E2\%80\%99s-top-10-emitters, (Erişim Tarihi 12 Mart 2016).

"United Nations Framework Convention on Climate Change", http://unfccc.int/files/essential_background/ background_publications_htmlpdf/application/pdf/conveng.pdf, (Erişim Tarihi 15 Şubat 2016).

WRI, Climate Resilience, http://www.wri.org/our-work/topics/climate-resilience, (Erişim Tarihi 22 Şubat 2015). 